\title{
Küresel Siyasette Moskova'nın Farklı Yüzleri: Covid-19 Salgını ile Mücadele ve Sputnik V
}

\author{
İbrahim KÖREMEZLi ${ }^{*}$
}

\begin{abstract}
Küresel Siyasette Moskova'nın Farklı Yüzleri: Covid-19 Salgını ile Mücadele ve Sputnik V

Özet

Rusya, küresel siyasette olumlu rol oynayan, başarlı ve sorumlu bir güç olduğu söylemi ile Batı'nın normatif üstünlüğüne meydan okumaktadır. Buna paralel olarak, Sputnik V aşısını bir başarı hikayesi olarak anlatan Moskova, uluslararası alandaki imajını güçlendirirken, rejimini antidemokratik ve yetersiz olmakla eleştirenlere cevap vermektedir. Neticede, Rus anlatısının kabul görmesi, dış politikasına ve stratejik kültürüne küresel anlamda duyulan sempatinin artması demektir. Ne var ki, bu anlatı herkese inandırıc gelmemektedir. Rusya'yı saldırgan ve revizyonist bir devlet olarak tanımlayanlara göre, Rusya'nın gücünü artıracağı herhangi bir hamleye izin vermek hatadır. Bu çalışma öncelikle otoriter ve demokratik rejimlerin pandemi ile mücadelesini kıyaslamaktadır. İkinci bölümde pandemi dönemi Rus dış politikası üzerine üç farklı anlatı - revizyonist, yardımsever ve pragmatist - incelenmektedir.
\end{abstract}

Anahtar Kelimeler: Sputnik V, Covid-19 Pandemisi, İmaj, Anlatı, Otoriterlik

\begin{abstract}
Different Faces of Moscow in Global Politics: Fighting against the Covid-19 Pandemic and Sputnik V

Abstract

Russia challenges Western normative superiority by claiming that it is a successful and responsible great power that plays a positive role in global politics. In this regard, the Russian image is strengthened through a success story over the Sputnik $V$ vaccine. It is a response to the criticisms that its regime is undemocratic and inadequate. The acceptance of the Russian narrative means increased sympathy to Russian foreign policy and strategical culture. This narrative, however, is not convincing for everyone. According to another perspective, Russia is an inherently aggressive and revisionist state. This study firstly compares the struggle of authoritarian and democratic regimes against the pandemic. Afterwards, three different narratives regarding Russian foreign policy during the pandemic - revisionist, responsible and pragmatist - are analyzed.
\end{abstract}

Keywords: Sputnik V, Covid-19 Pandemic, Image, Narrative, Authoritarianism

Paper Type: Research

\section{Giriş}

Dünyada Covid-19 salgınının her gün binlerce insanın canını aldığı 11 Ağustos 2020 tarihinde Kremlin bütün dünyaya önemli bir açıklamada bulundu. Bu açıklamaya göre Moskova'daki Gamaleya Araştırma Enstitüsü koronavirüse karşı etkili bir aşı geliştirmişti. (RT, 11 Ağustos 2020) Böyle bir haberin bütün dünyada sevinçle karşılanması beklenirdi. Fakat muhtelif tepkiler içerisinde en yaygını şüpheydi. (Foy, 13 Ağustos 2020) Batı başkentlerinden yükselen sesler Moskova'nın yaptığı açıklamanın bilimsel değil siyasi olduğu yönündeydi. Moskova ise dünyadaki ilk koronavirüs aşııını bulduğu tezine sımsıkı sarılmakla birlikte toplu aşılama faaliyetine ancak beş ay sonra Ocak 2021'de başlayabildi. Geçen aylar içinde Batı'da da farklı aşıların onayları alınmaya başlandı; fakat Ruslar Sputnik V'nin ilk başarılı aşı olduğu söylemini büyük bir tutkuyla sürdürmeye devam ettiler.

Rusya'nın uluslararası siyasette sahip olduğu farkı imajlar, Rus dış politikasının muhtelif şekillerde anlaşılmasını beraberinde getirmektedir. Koronavirüs ile mücadele ve aşı siyaseti de bu durumdan farklı değildir. Uluslararası siyasette ve akademide Rusya saldırgan ve revizyonist bir devletten, sorumlu büyük bir güce kadar farklı imajlara sahiptir. Kremlin ise doğal olarak Rusya'nın uluslararası siyasette olumlu bir rol oynadığını iddia eden anlatının güçlenmesi için uğraşmaktadır. Moskova, ayrıca Batı́yı zayfflayan bir medeniyet ve coğrafya olarak tanımlarken Batı́nın eleştirel anlatılarını tek taraflı ve kötü niyetli olmakla itham etmektedir. (Mölder ve Sazonov, 2020: 40-41)

\footnotetext{
* Ibrahim KÖREMEZLi, Dr. Öğretim Üyesi, Eskişehir Osmangazi Üniversitesi, Uluslararası İlişkiler Bölümü, ikoremezli@ogu.edu.tr, ORCID ID: 0000-0003-4130-8186
} 
Bu çalışma, Rusya'nın muhtelif imaj ve anlatılarından herhangi birini onaylama veya kanıtlama amacı taşımamaktadır. Buradaki hedef bir devletin ve bu devletin takip ettiği dış politikanın farklı bakış açıları ve hikayelerin parçası olduğu gerçeğinin altını çizmektir. Bu anlatıların her biri Rus siyasi kültürünün ve günümüz Rus dış politikasının farkı çehreleridir. Kısacası her devlet ve toplumun Rusya ile tecrübesi aynı değildir ve bu farklılık da muhtelif anlatıların ortaya çıkmasını beraberinde getirmektedir. Bunlardan sadece biri ile Rusya'yı tam olarak değerlendirmek mümkün değildir. Başka bir deyişle bu bakış açılarından bazılarını objektif diğerlerini taraflı olarak sunmak oldukça girift tarihi ve kültürel ilişkileri basitleştirmekten başka bir şey değildir. Benzer durum Rusya'nın koronavirüs ile mücadele ve aşı politikası için de geçerlidir. Kremlin'in dış politikasının bir veçhesi olarak yumuşak gücünü artıracak bir anlatııın güçlenmesi için gösterdiği gayret ise dikkati muciptir. Diğer taraftan, Kremlin'in her ifade ve eyleminin altında gizli bir amaç arayan anlatı da Moskova'nın sıklıkla başvurduğu askeri ve istihbari operasyonların doğal bir sonucudur. Son yıllarda, uluslararası düzen, dış politika ve jeopolitik krizlerin analizinde stratejik ve jeopolitik anlatıların ele alındığı bir literatür oluşmaktadır. (Miskimmon, O'Loughlin ve Roselle, 2013; Toal, 2017; Foxall, 2019; Tyushka, 2021) Bu çalışma söz konusu literatüre pandemi döneminde Rus dış politikası hakkındaki farklı anlatıları ele alarak katkı sunmayı amaçlamaktadır.

Bu makalede öncelikle otoriter ve demokratik yönetimlerin pandemi dönemi politikaları kıyaslanmışır. Zira otoriterliğin dünya siyasetinde oynadığı rol ve gördüğü kabul, Rusya imajını doğrudan etkilemektedir. íkinci bölümde Rus dış politikası hakkındaki üç farklı anlatı ele alınmıştır. Öncelikle, Rusya’yı uluslararası düzen ve hukuka saygılı bir devlet olarak gören ve özellikle Rusya'nın kendi imaj çalışmasında kullandı̆̆ı retorik tartışılıışır. Bu perspektife göre, Rus aşısı pandemiyle mücadelede mühim rol oynamaktadır. Sonrasında, Rusya'yı saldırgan ve revizyonist bir devlet olarak tanımlayan bakış açısı incelenmiştir. Bu anlatıya göre Rusya durdurulması gereken bir devlettir. Rusya'nın gücünü ve etkisini artıracağı herhangi bir hamleye izin vermek hatadır. Bu sebeple Moskova'nın etkisini artırmak için kullanabileceği Rus aşısı Sputnik V'ye karşı tedbirli olmak gerekmektedir. Son olarak ise Rusya'yı normal bir devlet olarak ele alan anlatı analiz edilmiştir. Buna göre, Rus dış politikası ulusal çıkar temelinde şekillenmektedir. Dolayısıyla, Rusya'nın komşu devletlerle sorunlar yaşamasında da, Rusya'nın aşıyı araçsallaştırmasında bu ülkeye özgü bir durum yoktur.

\section{Pandeminin Değiştirdiği Dünyada Demokrasi ve Otoriterlik}

\section{1. Zayıflayan Batı ve Değersizleşen Demokrasi Söylemi}

Pek çok gözlemci için Covid-19 salgını, II. Dünya Savaşı'nın sonundan bu yana Batı liberal uluslararası düzenindeki en büyük krizdir. Gelişmiş dünyanın krize tepkisi yavaş ve çoğu zaman etkisizdi. Salgından hiç beklenmedik bir şekilde etkilenen Batılı güçlerin sınırlııkları gözler önüne serilmişti. Bu devletler inanılması güç derecede beceriksiz davranmış, düzgünce çalışan bir acil durum stratejisi geliştirmede başarısız olmuşlardı. Hayatın olağan akışında gayet iyi çalışan siyaset ve kurumlar üzerlerindeki şaşkınlığı uzun süre atamamışlardı.

Batı dünyasının liderleri de kriz yönetiminde sınıfta kaldılar. ABD Başkanı Donald Trump ve Ingiltere Başbakanı Boris Johnson gibi bazı liderler, hastalığın ciddiyetini bile anlamada çok geciktiler. Böylelikle Batılı siyasetçiler ve siyaset bilimciler arasında 90'ı yıllarda ortaya çıkan liberalizmin mutlak zaferi düşüncesi büyük bir darbe aldı. Dolayısıyla, demokratik Batı́nın salgın karşııındaki başarısızlık ve çaresizliğinin uluslararası düzen açııından anlamı daha fazla tartışılmaya başlandı.

Avrupa ve $A B D$ 'nin salgınla mücadeledeki başarısızlığı, demokratik rejimlerin ve liberal uluslararası sistemin hanesine de yazıldı. Dolayısıyla, Avrasya'nın otoriter rejimleri Batı dünyasının bu beklenmedik acizliğini kendi avantajlarına kullanmakta gecikmediler. Özellikle, Rusya ve Çin başarı öykülerini cilalayarak hem kendi vatandaşlarına hem de dünyaya anlatmak konusunda oldukça istekliydiler. Böylelikle, salgının ölümcül etkilerini ortadan kaldırmak için mücadele eden Rus eliti, aynı zamanda Batı karşııı dış politika söylemini keskinleştirmiştir. Salgınla mücadelenin küresel bir ortaklı̆̆a dönüşmediği günümüz uluslararası ilişkilerinde, Kremlin Batı normatif üstünlüğünün altını oyan bir başarı öyküsü anlatmaktadır.

Batı́nın pandemi ile mücadeledeki başarısızlı̆ııın sebeplerinden bir tanesinin uzun yıllardır Batı sosyal yapısının dünyaya sunduğu en değerli şey olan insan hakları ve bireysel özgürlükler ile ilişkili olması önemlidir. Batı́nın özgürlükler bağlamında dünyaya anlattığı başarı hikayesi toplumsal kontrolün zorunlu olduğu pandemi gibi krizlerle 
mücadelede devlet için bir ayak bağı haline gelmiştir. Aslına bakılırsa Batılı liderlerin bireysel haklar ve özgürlükler ile sosyal kontrol ihtiyacını nasıl uzlaştıracakları konusunda bir planları yoktu. Devlet toplum ilişkisinde önceliğin kişisel özgürlüklere verildiği, devletin toplum ve birey üzerindeki kontrolünün zayıflığıın bir ilerleme kriteri olarak görüldüğü ülkeler, insanları kurallara uymaya çağıııken bunu icbar etme gücünden hem pratik hem de etik açıdan kendilerini yoksun hissettiler.

Günümüzde tartışılan tek şey insan sağlığı veya ölüm sayıları değildir. Pandeminin ekonomik etkileri insan hayatını zorlaştırmaya devam etmekte, sokağa çıkma yasakları ve kapanmalarla ilgili memnuniyetsizlik ABD ve Avrupa'da sıklıkla sokak gösterileri şeklinde tezahür etmektedir. Bu zaman zaman Avrupa başkentlerinde güvenlik güçlerinin sert tedbirler almasını beraberinde getirmektedir. Batılı hükümetlerin toplumsal hareketleri engellemeye çalışması ve sokak gösterilerine karşı çıkması dünyaya sunulan Batı imajı açııından bir tenakuz oluşturmaktadır. (Kowalewski, 2020: 3-4) Batı'da yükselen polis şiddeti Rusya ve Çin'den Batı́nın idealize ettiği özgürlük ve adalete sahip olmadığı şeklindeki eleştirilerin gelmesine sebep olmuştur. Nitekim, muhalif siyasetçi Aleksey Navalnıy'ın tutuklanmasına tepki olarak düzenlenen gösterilerin polis şiddeti ile engellenmesi konusunda yöneltilen eleştirilere cevaben Kremlin, Batı'da göstericilere karşı daha fazla şiddet kullanıldığını iddia etmektedir. (TASS, 3 Şubat 2021)

Açıkçası bireysel özgürlükler salgının kurbanlarından biri oldu. Sivil toplum, insan hakları, demokratik siyasi atmosfer üzerine Batı kökenli fikirlerin tümü, salgını kontrol altına almak için insanların izole edilme zorunluluğu sebebiyle ikincil hale gelmiştir. Yönetici elitler, gönüllü ya da gönülsüz bir şekilde insan ilişkilerini sınırlamaktadır. Siyasi toplantılar ve gösteriler bir yana insanların eğlenmek adına bir araya gelmeleri bile pandemi döneminde kriminal bir olaya dönüşmüştür. Böyle bir noktada, hükümetleri demokratik reformların veya kişisel özgürlüklerin eksikliği nedeniyle eleştirmek bir tutarsızlık haline gelmiştir. Başka bir deyişle, Batı'nın liberal değerler bağlamında sahip olduğu normatif üstünlüğü pandemi döneminde büyük bir darbe almıştır.

Diğer taraftan otoriter rejimler, pandeminin kontrolünün halk hareket ve davranışlarının kontrolü ile sıkı ilişkide olduğu günümüz konjonktüründe birçok avantaja sahiptir. Halkın özgürlük ve haklarının ertelenmesinin çoğunlukla normal olduğu Rusya ile karşılaştıııldı̆ında, Batı demokrasilerinde kriz yönetimi daha zordur. Özgürlük ve demokrasi, Batı'nın siyasete bakış açısının önemli bir parçası olduğu için, Batı hükümetleri tarafından alınan önlem ve kısıtlamalar toplum tarafından daha büyük bir dirençle karşılaşmaktadır. Bu sebeple günümüzde bireysel özgürlüklerin ne ölçüde dondurulabileceği veya ertelenebileceği Batı demokrasilerinde önemli bir sorudur. Pandemi srasındaki devletin toplum üzerindeki gözetimi, değişen devlet-toplum ilişkileri hakkındaki tartışmalara ivme kazandırmışıı.

Rusya'nın ana aktör olarak geri dönmesi ve Çin'in kayda değer yükselişi nedeniyle uluslararası sistemde Batı́nın üstünlüğü bir süredir sorgulanmaktaydı. Bugün, Amerikan hegemonyasının ve Batı normatif üstünlüğünün sert eleştirmenleri Batılı olmayan yükselen devletlerin pozisyonları daha da önemli hale geldi. Açıkçası pandemi, Batı düzeninin zayıfladığına dair anlatıyı güçlendirirken Batı liberal düzenine meydan okuyan ülkeler için uygun bir ortam sunmaktadır. Aynı zamanda Rusya ve Çin gibi otoriter devletlerin küresel sorunlarla mücadelede daha dirençli olduğu iddiası da güç kazanmıştır. Aslına baklırsa pandemi zaten dünyada bir süredir var olan bir eğilimin daha fazla görünür olmasını sağladı. Güçlü liderlik ve merkezi otorite salgının kasıp kavurduğu dünyada önem kazandı. Böylelikle özgürlüğe karşı düzeni, demokrasiye karşı egemenliği ön planda tutan devletler, tutumlarının ahlakiliği konusunda bugün daha yüksek sesle konuşabilmektedir.

\section{2. Rusya'nın Pandemi ile Mücadelesi: Otoriter Bir Başarı Hikayesi mi?}

Rus siyasi seçkinleri için Rusya'nın küresel ilişkilerde söz sahibi olmasının zamanı çoktan gelmişti. Kremlin, kendi yönetim tarzıı idealize ederek Rusya'nın prestijini artırmaya gayret etmektedir. Buna göre Putin Rusya'sı, Amerikan tek taraflıı̆ı̆ı ı vegemonyasını sert bir şekilde eleştirmekte, demokrasi bahanesiyle Batı müdahalelerine karşı çıkmakta ve daha demokratik bir dünya düzeni çağrısında bulunmaktadır. Günümüz Rus dış politikası, Batı hakimiyetindeki uluslararası sistemin gücünü ve kalııl lğını sorgulayan ve Rusya ile Çin için daha büyük bir rol öngören bir anlatıya dayanmaktadır. (Karaganov ve Suslov, 2018) Kısacası salgın dönemi politikasıyla Moskova, Batı'ya sadece bilimsel değil, aynı zamanda fikirsel anlamda da meydan okumaktadır. Bu sebeple Moskova'nın pandemi ile mücadelesini sadece sağlık ya da iç siyaset meselesi olarak görmek eksik olacaktır. Bu mücadeledeki başarı ya 
da başarısızlık Rusya'nın küresel politikada oynayacağı rolün büyüklüğü açısından da önemlidir. Dolayısıyla, pandemi ile mücadele otoriterlik ve demokratik liberal değerler arasındaki bir söylem rekabetinin de parçası haline gelmiştir.

Pandemi ile mücadelenin önemli bir veçhesini aşı bulma yarışı oluşturmaktadır. Koronavirüs aşısı ilaç şirketlerinin ekonomik hedefleri bir yana, Batılı devletler ile Çin ve Rusya gibi Batı harici yükselen güçler arasındaki bir imaj yarışına dönüşmüş durumdadır. Bu ise anlatıların yarıştığı, herkesin kendi hikayesini ön plana çıkarmak istedikleri bir mücadeleyi beraberinde getirmiştir. Rus aşısının küresel reklam ismi olarak belirlenen Sputnik V, Batı'ya açık bir mesajdır. Sputnik uzaya yollanan ilk yapay uydunun adıdır. 1957 yılında, Amerikalılar uzay araştırmaları ve füze teknolojisinde Sovyetler Birliği tarafından geride bırakıldıklarını şaşkınlık ve korkuyla öğrenmişlerdi. Şimdi ise Ruslar Sputnik V ile Batı́yı bir kez daha geride bıraktıklarını ima etmektedir. Pandeminin puslu havasında bu iddianın gerçekliğinin uluslararası siyasette güçlü yansımaları olabilirdi. Fakat, Ruslara göre dünyanın onaylanan ilk aşısı olan, Batılılara göre ise gerçek bir aşı olduğu bile tartışmalı olan Sputnik V şimdiye kadar (Mart 2021 itibariyle) küresel salgında mühim bir rol oynamadı. Bu durumu Kremlin bir başarısızıktan ziyade Batı'nın Rusya'nın önünü kesme çabası olarak yorumladı. Moskova'ya göre pandeminin ortadan kaldırılmasında kilit rol oynayabilecek böyle bir buluş sırf Batı'nın önyargılı tutumu ve inadı nedeniyle insanlığın kullanımına sunulamamıştı.

Batı́nın kendi problemleriyle boğuştuğu salgın döneminde Rusya ve Çin gibi otoriter devletlerin dış politika hedefleri daha iyi analiz edilmelidir. Salgına karşı küresel mücadeleye yardım etme, neoliberal uluslararası düzene meydan okuma, otoriter eğilimlerin baskın olduğu yeni bir uluslararası yapı kurma ya da kendi nüfuz alanını koruma gibi hedeflerden hangisi Rus dış politikasını daha iyi tanımlamaktadır? Bu sorulara verilecek cevaplar otoriter devletlerin uluslararası düzendeki konum ve rollerinin tespiti açısından önemlidir. Rusya ve Batı arasındaki bakış açılarındaki farklılıklar Rusya'nın pandemi dönemi dış politikası ve aşı siyaseti hakkında farklı okumaları da beraberinde getirmektedir. Bundan sonraki bölüm üç farklı bakış açısıyla Rusya’nın pandemi ile mücadelesini ve aşı siyasetini değerlendirecektir.

\section{3. Üç Farklı Moskova Hikayesi}

Devletleri mutlak iyi ya da kötü olarak değerlendirmek mümkün değildir. Dış politikaların her zaman rasyonel zeminde yürütüldüğünü söylemek de çok iddialıdır. Diğer taraftan her devlet kendi dış politikasının iyi niyetli ve rasyonel olduğunu savunurken rakiplerini sıklıkla olduklarından daha agresif veya irrasyonel olarak görmektedir. Dolayısıyla, algılardaki farklııklar, kamu diplomasisi faaliyetleri, geçmiş düşmanlık ve dostluklar devletlerin dış politikaları hakkında farklı anlatıların inşasını beraberinde getirmektedir.

Birçok devlet dış politika açıklamalarında aşı milliyetçiliğine karşı çıkarak Covid-19 aşılarının adil dağıtımının gerekliliğinin altını çizmiştir. Fakat, bu ulaşılması kolay bir hedef değildir. Salgınla mücadele küresel bir çabaya dönüşemediği gibi, devletler kendi ulusal stratejilerini takip etmeye mecbur kalmışlardır. Daha da kötüsü, aşı geliştirme ve aşılama faaliyetleri, Batı demokrasileri ile Avrasya'nın otoriter rejimleri arasında bir yarışa dönüşmüştür. Bölünmüş bir dünyada aşı diplomasisi dış politika gündeminin önemli bir parçası haline gelmiştir. Batılı ülkeler Rus ve Çin aşısı almayı planlarına dahil etmezken, Rusya ve Çin ise kendi bilimsel çabalarına ve üretim kapasitelerine güvenmeyi tercih etmiştir. Bu noktada, zayıf ve fakir devletler, halklarını aşılamak için güçlü dostlara ve başarılı bir diplomasiye güvenmek zorunda olduklarını anlamışlardır. (Lomsadze, 2021)

Yukarıda da izah edildiği gibi Batı ittifakı son yıllarda belki de hiç olmadı̆̆ı kadar sorgulanmaktadır. Türkiye gibi NATO veya Macaristan gibi $A B$ üyesi devletlerde Rusya etkisinin artması, Batı ittifakının geleceği hakkındaki tartışmaları beraberinde getirmektedir. AB'nin aşılama konusunda yavaş davranması da bazı üye ülkeleri Rusya ve Çin'e yaklaştırmıştır. AB ülkeleri arasında bile aşının nasıl adil bir şekilde pay edileceği konusunda bir uzlaşma sağlanamamıştır. Bu durum birliğin normatif ve ahlaki zeminini sarsarken, içeriden ve dışarıdan yükselen eleştiriler birliğin pandemi sonrasındaki geleceği konusunda şüpheleri artırmıştır.

Rusya'nın gelişmekte olan ülkelerle ve bazı AB ve NATO üyeleriyle son dönemde geliştirdiği ilişsi Moskova'nın küresel siyasetteki imajı açısından önemlidir. Slovakya ve Rusya arasındaki aşı işbirliği bu konuda güzel bir örnektir. Slovakya Sputnik V aşısı için Rusya ile anlaşma yapan Macaristan'dan sonraki ikinci AB ülkesidir. Bu anlaşmaya muhalif siyasiler hem AB'ye hem de Slovakya'ya zarar verdiği gerekçesiyle sert eleştiriler getirirken Slovak Başbakanı 
Igor Matovic'in bu eleştirilere cevabı oldukça manidardır: "Virüs jeopolitik tanımıyor.” (Dudik, 2021) AB'nin aşılamadaki başarııızığı ve Slovak halkının sağlığııı korumadaki çaresizliği ülkeyi Rus aşısına yöneltmiştir. Peki Moskova, Slovakya'ya yardım etmek, AB'yi parçalamak, Batı'nın imajına zarar vermek gibi hedeflerden hangisiyle hareket etmektedir? Aşağıdaki üç ayrı Moskova tasviri pandemi dönemindeki Rus stratejisini ve bu stratejinin farkılı algılanış biçimlerini anlamamıza yardımcı olabilir.

\section{1. Sorumluluk Sahibi İyi Niyetli Bir Güç: Rusya'nın Aşı Yardımı}

Dünyadaki aşı paylaşımındaki adaletsizlik Batı́nın hanesine yazıımıştır. Pandemiyi kontrol etmek amacıyla daha çok iç politikalarına yönelen bu devletler, küresel imajlarını zarar verecek politikalar takip etmekten çekinmemişlerdir. Mesela, ABD, ìngiltere ve Kanada gibi Batı ülkelerinin, ihtiyacının birkaç katı aşı sipariş etmesi, halkını düşünen bir iktidar anlayışından çok bencillik olarak görülmüştür. "Zengin ülkeler rafları boşalttı" haberi Batı ülkelerinin pandemiden kurtulmak adına takip ettikleri aşı politikasını sarih bir şekilde göstermektedir. (NYT, 2020) Böyle bir siyasetin tabii neticesi fakir ülkelerin aşıya ulaşmalarının neredeyse imkansız hale gelmesidir. Zengin ülkelerin 39 milyon aşıya ulaşırken fakir bir ülkenin sadece 25 aşı alabildiğini aktaran Dünya Sağlı Örgütü (DSÖ) Genel Direktörü Tedros Adhonam Ghebreyesus, bu durumu oldukça etkileyici bir biçimde özetliyordu. Ghebreyesus'a göre dünyadaki aşı dağılımı ahlaki bir başarııızıktır. (BBC, 2021) Uluslararası aşı paylaşım programı COVAX'ın yavaş ilerlemesi düşük gelirli ülkeleri daha da çaresiz bırakmıştır.

İşte bu ortamda Latin Amerika, Afrika ve Asya'nın fakir ülkeleri yüzlerini Rusya ve Çin'e çevirmişlerdir. Rusya'nın RT haber portalında köşe yazıları kaleme alan Tom Fowdy (2021) küresel sağlık düzeninin değiştiğini iddia etmektedir. Batı fakirlere yardım eden zengin ve gelişmiş bir coğrafya imajını kaybederken, günümüzde bu rolü milyonlarca aşııı fakir ülkelere gönderen Rusya ve Çin devralmışır. Aşı paylaşımındaki adaletsizliğin Batı imajına zarar verdiği şüphesizdir. Batı devletlerinin kendilerini önceleyen aşı politikaları, gelişmekte olan fakir ülkeleri Rusya ve Çin ile işbirliğine yönlendirmiştir. Moskova ve Pekin'in bilimsel başarılarını gelişmekte olan dünya ile paylaşmaya hazır oldukları iddiası da bu ülkelerin yardımsever imajlarına güç kazandırmıştır.

Aşı yarışında Batı'da ekonomik hedefler peşinde koşan özel şirketler ön planda iken, Kremlin Sputnik V'yi dış politikasının hayati bir parçası olarak kabul etmektedir. Sputnik V Rusya'nın Doğrudan Yatıım Fonu (RDIF) tarafından uluslararası pazarlara taşınmaktadır. Fakat bu ticari bir girişimden daha çok küresel bir sorunu çözmek için işbirliği ve yardımlaşma hareketi olarak sunulmaktadır. İç tüketim için gerekli aşı miktarıı bulmakta güçlük çekmesine rağmen Rusya, Sputnik V aşılarıı Beyaz Rusya ve Arjantin'e göndermekte tereddüt etmemiştir. (Aljazeera, 2020) Rusya'nın aşı diplomasisi, dış politikanın diğer alanlarında işbirliğini de artırmayı hedeflemektedir. Dolayıııla, Afrika veya Asya devletlerinin, koronavirüs ile mücadele kapsamında Rusya ile işbirliklerini artırmaları şaşıtııı olmayacaktır.

Aşının yollandığı ülkelere her geçen gün bir yenisi eklenmektedir. Diğer taraftan Rusya'nın çok büyük bir üretim kapasitesi mevcut değildir. Dolayısıyla gönderilen aşı miktarı her ne kadar tam olarak paylaşılmasa da günümüze kadar sınırı sayıda aşı gönderilmiş olmalıdır. Fakat aşının hâlâ çok değerli olduğu düşünüldüğünde mütevazı rakamların dahi önemli olduğu söylenebilir. Bu arada üretim kapasitesinin artııılması için Brezilya, Güney Kore ve Kazakistan'da ortak üretim yapacak fabrikaların devreye girmesi ile Mart ayında 40 milyon aşı üretilmesi beklenmektedir. (Light ve Sauer, 2021) Moskova'nın aşı üretimi konusunda yaptığı işbirliği anlaşmaları ve Sputnik V'nin muhtelif ülkelerden aldığı onaylar sonucunda Rus aşısının güvenilirlik ve marka değerinin arttığı söylenebilir.

Rus haber sitelerinde hemen her gün Sputnik V aşısı ile ilgili yeni gelişmeler paylaşılmaktadır. Buna göre sipariş veren ülkelerin sayısı güncellenmekte, bu ülke siyasilerinin Sputnik V'nin etkinliği ve Rus bilimi hakkındaki övgü dolu görüşlerine yer verilmektedir. Sırbistanlı bir bakanın ve Meksika başbakanının Rus aşııını ve Rus bilimini öven ifadeleri bu meyandadır. (TASS, 29 Ocak 2021; RIA, 2021) Mart ayının başı itibariyle kırkın üzerinde ülke veya siyasi yapı Rus aşııına onay vermişsir. (Sputnikvaccine, 2021) Bu sayı Mayıs ayı ortalarında altmışı geçmiştir. (Reuters, 2021)

Rusya'nın son dönemde Batı ile ilişkilerinin bozulması, onu sadece dış politikada yeni arayışlara itmemiş, aynı zamanda Batı'nın söylem gücüne karşı inandıııı bir retorik geliştirmeye zorlamıştır. Rusya, otoriter, saldırgan, yayılmacı bir devlet olarak resmedilmek istememektedir. Rus basın ve medyasının uzun zamandır dillendirdiği anlatı 
Rusya'yı sorumlu büyük bir güç olarak tasvir etmektedir. Rusya'nın koronavirüs ile mücadelesi ve aşı siyaseti de bu genel stratejinin bir parçasıdır.

Kremlin, Rusya'yı Batı'nın çifte standartlarından, samimiyetsizliğinden, küstahlığından ve bencilliğinden uzak, bir büyük güç olarak sunmaktadır. Batı ise jeopolitik çıkarlarını önceleyen dış politikasıyla devletlerarası işbirliğini sekteye uğratan bir coğrafya olarak tasvir edilmektedir. Rusya Dışişleri Bakanı Sergey Lavrov, pandemi sırasında Batı politikalarını sert bir şekilde eleştirirken Moskova'nın uluslararası işbirliğini ilerletme iradesini ve kapasitesinin altını çizmiştir. (TASS, 30 Aralık 2020) Buna göre Batı saldırısı altındaki Rusya uluslararası düzenin korunmasında mühim role sahiptir. Başka bir deyişle uluslararası düzenin geleceği konusunda Rusya revizyonist değil tam tersi muhafazakârdır. Rusya, uluslararası hukuka saygı gösterilmesini, bölgede ve dünyada düzen ve istikrarın korunmasını istemektedir. (Istomin, 2021)

Batı́nın olumsuz özelliklerinden azade olan Rusya, iki yüzlü ve çıkarcı değildir. Diğer devletlerin hükümranlık haklarına saygı gösterdiği gibi yayılmacı amaçlar da taşımaz. Bu bakış açısı Rusya'yı uluslararası siyasette etkili ve müspet rol oynayan bir devlet olarak tasvir eder. Bu olumlu rol Rus stratejik kültürünün de bir neticesidir. Zira Rusya'yı mesiyanik kurtarıcı bir devlet olarak görmek, onu dünya siyasetinin yönlendiricisi, zayıfların koruyucusu olarak tasavvur etmek yeni bir şey değildir. (Engström, 2014) Nasıl ki Çarlık döneminde Ortodoksların, Sovyet döneminde sosyalistlerin ve emekçilerin hakkını koruma misyonunu üstlendiyse günümüz siyasetinde de Rusya, Batı yayılmacılığına karşı koymak gibi bir misyona sahip olduğu iddiasındadır.

\section{2. Uluslararası Düzene Meydan Okuyan Revizyonist Bir Güç: Rusya'nın Aşı Silahı}

Birçok siyasetçi ve siyaset bilimci için Rusya liberal uluslararası düzenin baş düşmanıdır. Marlene Laurelle'e (2015: 20) göre Rusya uluslararası düzeni değiştirmek istemekle birlikte yerine ne koyacağını tam olarak bilmemektedir. Özellikle Putin dönemindeki sert dış politika söylemi, komşu devletlerle sahip olunan inişli çıkışı ilişki, en önemlisi 2008 yılında Gürcistan ve 2014 yılında Ukrayna'ya yapılan askeri müdahaleler Rusya'nın saldırgan ve tehlikeli ülke imajını güçlendirmiştir. Rusya'nın 2016 yılındaki ABD seçimlerine ve Brexit referandumuna müdahil olduğu şeklindeki bulgular, bu ülkenin Batı ittifakı için yıkıcı bir güç olarak resmedilmesini beraberinde getirmiştir. Şeytanileştirilmiş Rusya tasviri Rusya karşıtı siyasetin meşrulaştırma zeminini oluşturmaktadır. Böyle bir tasvirin doğruluk ve yanlışlığı bir tarafa, uluslararası siyasette yerleşik ve güçlü Rusya imajlarından bir tanesinin son derece olumsuz olduğu bir gerçektir. Rusya'nın irrasyonel ve kötücül bir güç olarak değerlendirilmesi, büyük oranda tarihi tecrübe ve hafıza ile ilgilidir. Açıkçası, Soğuk Savaş güncel siyaset üzerindeki etkisini henüz kaybetmiş değildir.

Böylelikle son dönem Rus dış politikası sıklıkla revizyonist, rövanşist ve yayılmacı olarak nitelendirilmiştir. Bu anlatının en hararetli temsilcileri daha evvel Rus etkisi altında yaşamak zorunda bırakılmış Rusofobi'nin hem toplum hem de siyasi elitler arasında yaygın olduğu Baltık ülkeleri, Polonya ve Ukrayna'dır. Rusya'ya karşı sert bir dış politika izlenmesi gerektiğini düşünen 1990'lı yıllar Amerikan siyasetinin etkili isimleri Zbigniew Brzezinski ve Madeleine Albright'ın Doğu Avrupa'da doğmuş olmaları elbette bir tesadüf değildir. Rusya'yı Avrupa için tehdit olarak gören siyasiler yine Moskova'ya karşı dikkatli olunması gerektiğini düşünmektedirler. ABD küresel hegemonyasının insan hakları ve demokrasinin korunması için elzem olduğu iddiasındaki Amerikalı siyasiler ve siyaset bilimciler de Rusya'ya karşı sert bir söylem benimsemişlerdir.

Rusya algısında tarihi ve coğrafi faktörlerin de mühim yeri vardır. Rusya coğrafi olarak dünyanın en geniş devletidir. Rus tarihi büyük oranda savaş ve yayılmanın tarihidir. (Kotkin, 2016: 2) Bundan dolayı genişleme arzusunun ve bitmez tükenmez bir güvenlik arayışının Rus devlet karakterinde mündemiç olduğunu iddia edenler olmuştur. Bu bakış açısının en meşhur temsilcisi çevreleme politikasının da mimarı olan George F. Kennan'dır. (1947) Kısacası Rusya bir taraftan komşularına güven vermezken ironik bir şekilde kendisini de güvende hissetmeyen bir devlete dönüşmüştür. Bu durum elbette Rus dış politika anlatısına da sirayet etmiştir. Geçmişte Moskova idaresinde yaşamak zorunda kalan halklar, şimdi Rusya siyasetine kuşku ile bakmaya devam etmekte, günümüz Rus dış politikası da bu şüphe ve korkuyu beslemektedir.

Moskova bozucu ve yıkıcı bir güç olarak tasvir edilirken devletler arası güç mücadelesi iyi ile kötü, doğru ile yanlış arasındaki bir hesaplaşma şeklindeki bir anlatıya dönüşmektedir. Bu cümleden doğal gaz ve komşu ülkelerde yaşayan Rus diasporası Rus dış politikasının araçları/silahları mahiyetindedir. Yaklaşık yirmi yıldır, Moskova'nın dış 
politikası, komşu ülkelere karşı Rus enerjisini ve diasporasını araçsallaşıırıa (ve hatta silahlaştırma) başarısıyla ilgili olarak ele alınmışıı. (Blank ve Kim, 2016; Pieper, 2020) Kremlin'in son yıllarda kendi anlatısını güçlendirmek için başvurduğu yöntemler de "anlatıyı silahlaştırma" olarak tasvir edilmiştir. (Tyushka, 2021) Bu nedenle, Rusya söz konusu olduğunda, normalde insani veya ekonomik konular bile güç siyasetinin meseleleri olarak kabul edilmektedir. Batılı siyasetçiler salgın sırasında Kremlin'in hedeflerinden şüphelenerek Rusya'yı aşıyı siyasallaştırmakla suçladılar. Özellikle bir zamanlar Moskova'nın kontrolünde olan ve Rusya sınırlarına yakın olan Polonya ve Baltık devletleri, Kremlin'in Doğu Avrupa'daki etkisini artırmak için aşııı bir dış politika aracı olarak kullanabileceği konusunda endişelidir. (Tanner, 2021) Bu bakış açışına göre, Rusya apaçık yayıımacı hedefler taşıyan ve bu amaçla her türlü vasıtayı mubah sayan bir devlet olduğu için, Rus aşısı uluslararası düzene, bölgesel barışa yöneltilmiş jeopolitik bir silahtan başka bir şey değildir. (The Baltic Times, 2021)

Aslına bakııırsa, Kremlin'in aşı geliştirme hikayesi de bu bakış açısını desteklemektedir. Kremlin, üçüncü aşama - insanlar üzerinde test- tamamlanmamış olmasına rağmen, aşı kullanımını hızlı bir şekilde onaylamıştı. Koronavirüs ile küresel mücadelede onaylanmış ilk aşıya sahip olmak Rus yönetimi için faydalı bulunmuştu. Burada amacın Rusya'nın uluslararası imajını güçlendirmek olduğu açıktı. Kremlin, aşııını diğer büyük güçlerden daha erken geliştirerek Rus biliminin Batı biliminden aşağı olmadığını göstermeye çalışmışıı. Kısacası, Rusya’nın koronavirüs aşııı siyasetini geleneksel Rus politikasından ayrı düşünmek mümkün değildir.

Rusya, aşısının AB tarafından onaylanmasını sabırsılıkla beklemektedir. (Mayıs 2021 tarihi itibariyle Sputnik V'nin $A B$ tarafından onay süreci henüz sonuçlanmamıştır.) Fakat Kremlin'in $A B^{\prime} y e$ üye devletlere aşı satma isteği de saldırgan dış politikanın bir parçası olarak algılanmaktadır. Diğer taraftan her ne kadar Rus aşısı onay almamış olsa da Rusya, bazı Avrupa ülkeleriyle aşının ithali ve ortak üretimi konularında anlaşmaya varmışır. Buradaki öncelikli amacın ekonomik olduğunu söylemek zordur. Dünyada günlük vakalar ve ölüm oranları konusunda Rusya ilk sıralarda yer almaktayken, kendi ihtiyaç duyduğu aşıyı başka ülkelere ihraç etmesi nasıl anlaşılmalııır? Kremlin'in kendi salgın meselesini çözmeden AB'ye aşı satmak konusunda bu kadar istekli olması Rusya'nın niyeti hakkındaki şüpheleri daha da artırmışıtır. Avrupa Komisyonu Başkanı Ursula von der Leyen'in, "Kendi halkını aşılaması yeterince ilerlemiyorken, Rusya'nın neden teorik olarak milyonlarca ve milyonlarca doz [aşı] teklif ettiğini merak ediyoruz" ifadesi AB'nin şüphesinin en üst düzeyde bir izharıydı. (Collis ve Martuscelli, 2021)

Ukrayna'nın doğusunda Moskova'nın tahrik ettiği bir savaş devam etmesine ve hatta pek çok kişi Rusya'nın aşıyı bir dış politika aracı ve hatta silahı olarak kullanmak istediğini düşünmesine rağmen Ukrayna bile Rus aşııını kullanma ihtimalini tartışmışıı. Bu Slovak başbakanın ifade ettiği realiteyle ilgilidir. Amerikan dış politikası, aşıya erişmek için Avrasya ile Batı arasında sıkışıp kalan eski Sovyet müttefiklerine güven vermemiştir. Fakat Kiev hükümeti Ukrayna'daki Rusya yanlısı siyasetçiler ve medya tarafından desteklenen Sputnik V'yi jeopolitik bir mesele olarak gördüğü için Rus aşısını yasaklayarak tartışmalara son noktayı koymuştur. Kiev’e göre Rus aşııı “Rusya’nın Ukrayna'ya karşı hibrit bir silahıdır." (Reuters, 2021)

Öncelikle Rusya'nın son dönem dış politikasının en önemli amaçlarından biri olarak tartışılan Batı ittifakını içeriden zayıflatmak konusunda aşının bir rolü olabileceği düşünülmektedir. $A B$ üyesi ülkelerin Rusya'ya aşı konusundaki tavırları farklılaşmakta ve bu konuda AB'nin ortak bir politika üretemediği görülmektedir. Kısacası Batı ittifakı içerisindeki farklı bakış açılarının dış politika oluşumunda ayrılıkları beraberinde getirmesi Rusya'nın istediği bir gelişmedir. AB ve NATO içerisindeki çatlaklar Rusya'nın Doğu Avrupa ve eski Sovyet coğrafyasında daha etkili bir siyaset izlemesini de beraberinde getirebilir.

Günümüzde aşı, adeta peşinden koşulan nadir ve değerli bir madene dönüşmüş durumdadır. Devletler arasındaki aşı rekabeti doğal kaynaklar için yapılan jeopolitik mücadeleyi andırmaktadır. Bu arada Batı merkezli çok uluslu şirketlerin devletlerden bağımsız hareket ederek kâr maksimizasyonunu hedefledikleri görülürken, hükümetler bu şirketlerden daha fazla aşı almak için büyük gayret sarf etmektedir. Fakat burada siparişi erken veren ve parayı önce ödeyen kazanmaktadır. Başka bir deyişle Batı'da kapitalizmin kuralları pandemi şartlarında da kendini göstermektedir. Batılı uluslar umutsuzca kendilerini kurtarmaya çalışıken ve dünyanın daha fakir bölgelerine yardım etme yetenek ve iradesini gösteremezken, Çin ve Rusya, dünya toplumunu daha sorumlu ve cömert davrandıklarına ikna etme avantajına sahip görünmektedir. (Chassany, 2021) 
Pandemi, dünyanın ikiye bölündüğünü ve birlik içinde hareket edemediğini açık bir şekilde gösterdi. Bu dönemde, Rusya ile Batı arasındaki işbirliğinden ziyade, birbirlerinin niyetleri hakkındaki şüpheler arttı. Rusya, Çin ve İran, yabancı ortaklarla herhangi bir bilimsel işbirliği olmaksızın kendi aşılarını ürettiler. Koronavirüsün ağır darbe aldığı ülkelerden biri olan Rusya, kendi kendine yeterli büyük bir güç olduğunu göstermek için hiçbir yabancı ilaca veya aşıya başvurmadı. Bu arada, Rus ve Çin medyası Batı aşılamasının başarısızıkları ve Batı kökenli aşıların negatif etkileri hakkında haberler yapma konusunda birbirleriyle yarıştılar.

ABD dışişleri bakanlığı ve istihbarat çevrelerine göre, İspanyolca konuşan ülkeleri Sputnik V aşısının Batılı rakiplerinden daha iyi çalıştığına ikna etmek için Moskova kontrolündeki İspanyolca yayın yapan medya kuruluşları tarafından bir dezenformasyon kampanyası gerçekleştirilmiştir. (Frenkel, Abi-Habib ve Barnes, 2020) AB Dış ilişkiler ve Güvenlik Politikası Yüksek Temsilcisi Josep Borrell de, Rusya'yı Batı tarafından geliştirilen aşılar hakkında yanlış bilgiler yaymakla suçladı. Borrell'e göre, dezenformasyon Sputnik V için olası pazarlarda Batı aşısının itibarını sarsmayı hedeflemektedir. (Reuters, 2020) Diğer taraftan Kremlin sözcüsü Dmitry Peskov, Rus aşısının pazara girmesinin küresel ilaç şirketleri tarafından engellendiğini iddia etti. Peskov’a göre, aşı rekabeti politize olduğu gibi, Batılılar Rus aşısının itibarına zarar vermek için kirli yöntemler kullanmaktadır. (TASS, 11 Aralık 2020) Benzer şekilde, Vladimir Putin ile sansasyonel bir röportaj da gerçekleştirmiş olan Amerikalı ünlü film yapımcısı Oliver Stone, Rusya'da Sputnik V aşısı vurulduktan sonra Batı'yı bu aşıyı dikkate almamakla eleştirmiştir. (The Moscow Times, 2020)

Amerikan şirketleri Pfizer ve Moderna tarafından yapılan aşılarla karşılaştırıldığında, Sputnik V sadece daha ucuz değil, aynı zamanda kompleks bir soğuk zincire ihtiyaç duymadığı için saklanması ve taşınması da daha kolaydır. Bununla birlikte, aceleci bir şekilde onaylanması ve çarpıcı bir biçimde isimlendirilmesinden dolayı Sputnik V'nin bilimsel bir proje olarak etkinliği hâlâ tartışmalıdır. Sonuç itibariyle, Rusya'nın son yıllardaki revizyonist dış politikası ve Batı ile bozulan ilişkileri, Rus aşısının pandemiye karşı küresel mücadelede daha geniş ve etkin bir rol oynamasını engellemiştir.

\section{3. Değişen Dünyada Pragmatist Bir Güç: Küresel Aşı Yarışında Rusya}

Rus dış politikası hakkındaki üçüncü anlatı onu çıkarı peşinde koşan ve güvenliğini sağlamayı önceleyen pragmatist bir devlet olarak ele alır. Bu bakış açısına göre Rusya'ya olumlu ya da olumsuz değerler yüklemek yersizdir. Rus dış politikasını anlamak için Rus çıkar ve hedeflerini bilmek gerekir. Rusya ile sağlıklı ilişki kurmak isteyen devletlerin Rusya'yı şeytanlaştırmaktan da onu mesiyanik hedefler peşinde koşan kurtarıcı bir devlet olarak görmekten de kaçınmaları gerekir. ABD’nin de dış politikasında Rusya'nın önceliklerini dikkate almasının vakti gelmiştir.

Bu yaklaşıma göre Rusya çıkarlarına göre revizyonist ya da pasifist şekilde hareket edebilir. Fakat Rusya özünde kötü ya da yayılmacı değildir. Putin'i gücü kutsayan, bunun için her yolu mubah gören anakronik bir lider olarak değerlendirmek de yanlıştır. Rusya rasyonel hareket eden bir devlet, Putin ise onun pragmatist lideridir. John Mearsheimer Rusya'nın Kırım'ı ilhakı hakkındaki değerlendirmesinde Putin'in irrasyonel olmamakla birlikte korkulacak ve saygı duyulacak bir stratejist olduğunu ifade etmiştir. (2014: 84) Bu bakış açısına göre Rusya'nın Kırım'ı ilhakı ve Gürcistan'a operasyonu Batı'nın hamlelerine karşı kendini korumaya çalışmasından ibarettir. Bunları özünde yayılmacı bir devletin dış politikası olarak görmek abartı olacaktır.

Rusya yarış içerisinde olduğu Batı karşısında öne geçmek istemektedir; fakat Rusya'nın tutumunun Batı devletlerinkinden farkı yoktur. Devletin muhafazası ve düzenin sağlanması Kremlin'in öncelik verdiği hedeflerdir. Hal böyle iken uluslararası sistemin altını oymak ve sistemi istikrarsızlaştırmak Rusya'nın istemeyeceği şeylerdir. Rusya, Soğuk Savaş sonrası ortaya çıkan ABD merkezli uluslararası yapıyı son dönemde giderek artan bir şekilde eleştirmektedir. ABD hegemonyasının belirgin olduğu tek kutuplu uluslararası yapının çok kutupluluğa evirilmesinin daha barış̧̧ı bir düzenin inşası için gerekli görmektedir. Aslında Rusya'nın istediği ABD’nin tek taraflı revizyonist hareketlerini terk etmesidir. Diğer taraftan ise NATO genişlemesi, Renkli Devrimler ve Arap Baharı gibi sokak gösterileri Batı'nın demokrasi anlayışını ve bu anlayışını ihraç etme stratejisini Rusya açısından problemli ve tehlikeli hale getirmektedir. Dolayısıyla, Rus jeopolitik anlatısı, Batı'nın Rusya'nın yükselişine karşı olduğunu, çok taraflı bir uluslararası sistemin kurulmasını engellemeye çalıştığını ve Batı demokrasisinin geliştirilmesinin, içişlerine müdahale etmek ve diğer devletlerin egemenlik haklarını azaltmak için yalnızca jeopolitik bir araç olduğunu savunmaktadır. Rusya uluslararası kurumların ve hukukun önemine inanmaktadır. (Istomin, 2021) 
Rusya, Batı liberal düzeninin üstünlüğü fikrinin muhtemelen ortadan kalkacağı pandemi sonrası dönemde jeopolitik rolünde dramatik bir değişiklik beklemektedir. Rusya'nın iddiası, küresel siyasette daha büyük bir role sahip olmakla ve yeni bir dünya düzeni inşa etmektense muhtemelen $A B D$ ile eşit bir duruş sergilemekle ilgilidir. Dolayısıyla pandemi döneminde Rusya çıkarlarının peşinde koşan ve çıkarları gerektiğinde işbirliği yapmaktan da rekabeti sürdürmekten de çekinmeyen bir devlettir.

Sadece Rusya değil bütün devletler aşı milliyetçiliği yapmakta ve pandemi ortamında ulusal çıkarlarını korumaktadır. Buna göre, Rus aşısını da geleneksel Rus politikasından ayrı düşünmek mümkün değildir. Koronavirüs aşııının geliştirilmesi ve üretilmesinin çok ciddi ekonomik ve politik sonuçları vardır. Aşı için arzın üzerinde bir pazar büyüklüğü olduğu açıktı. Fakat Kremlin için maddi kazançtan ziyade stratejik kazançlar daha ön planda olabilir. Aşı ihracatı, hibesi ya da ortak üretimi ülkelerin Rusya ile başka konularda da işbirliği yapmalarını beraberinde getirebilir.

\section{Sonuç}

Bu çalışma Rusya'nın pandemi ile mücadelesini küresel politikada Rusya'nın rolü ve bu rol hakkındaki farkı anlatılar temelinde tartışmışıı. Moskova'nın pandemi hedefleri ve aşı siyaseti birbirinden farklı üç anlatının konusu olmuştur. Rusya, kendisini sorumlu ve yardımsever büyük bir güç olarak tasvir ederken, Batı kamuoyunda revizyonist, saldırgan ve bozucu bir devlet olarak ele alınmışıı. Diğer taraftan, Rusya'yı küresel sistemin doğal ve normal bir üyesi olarak kabul ederek sadece çıkarları peşinde koşan bir güç olarak değerlendirmenin daha doğru olduğunu iddia edenler de vardır. Bu çalışma her üç anlatının da Rus dış politikasını ve hedeflerini anlamamıza yardımcı olabileceğini öne sürmektedir. Zira, Rusya dış politikasının bütüncül değerlendirilebilmesi için her üç bakış açısına da ihtiyaç vardır.

Dolayısıyla, bu çalışma herhangi bir hiyerarşi uygulamadan Kremlin'in pandemi ile mücadele stratejisi ve aşı politikasının muhtelif anlatılarını tartışmışı. Rusya'nın sadece kendi anlatısııı doğru olarak alması, diğerlerini yanlı ve kötü niyetli olarak damgalaması, bu ülke hakkındaki negatif fikirleri bertaraf etmeyecektir. Tek taraflı ABD politikaları ve pandemi etkisiyle Batı normatif üstünlüğü hakkındaki şüpheler artmakla birlikte, gizli operasyonları ve dezenformasyonu dış politikasının bir uzantııı haline getiren Rusya'nın sadece yumuşak güç araçlarıyla iyiliksever bir devlet imajını kuvvetlendirmesi de zor gözükmektedir. Kısacası Rusya'nın küresel siyasette daha olumlu bir imaja sahip olması için bunu destekleyecek dış politika pratiklerine ihtiyacı vardır.

\section{Araştırma ve Yayın Etiği Beyanı}

Bu makale için etik izin alınmasını gerektirecek bir durum söz konusu değildir.

\section{Destek Beyanı}

Makale herhangi bir kurum veya kuruluş tarafindan desteklenmemiştir.

\section{Çıkar Beyanı}

Bu makale ilgili çıkar çatışması durumu söz konusu değildir.

\section{Kaynaklar}

Aljazeera. (2020, 29 Aralık). Argentina Begins COVID Vaccine Campaign with Russian Shots. Erişim adresi https://www.aljazeera.com/news/2020/12/29/argentina-begins-vaccine-campaign-with-russias-sputnikv

Blank, S. ve Kim, Y. (2016). Economic Warfare a la Russe: The Energy Weapon and Russian National Security Strategy. The Journal of East Asian Affairs, 30 (1), 1-39.

BBC. (2021, 18 Ocak). Covid vaccine: WHO warns of 'catastrophic moral failure'. Erişim adresi https://www.bbc.com/news/world-55709428

Chassany, A. (2021, 10 Şubat). The West Should Pay Attention to Russia and China's Vaccine Diplomacy. Financial Times. Erişim adresi https://www.ft.com/content/c20b92f0-d670-47ea-a217-add1d6ef2fbd

Collis, H. ve Martuscelli, C. (2021, 17 Şubat). Russia's 'geopolitical' vaccine: Is Sputnik too good to be true? Erişim adresi https://www.politico.eu/article/russia-sputnik-geopolitical-coronavirus-vaccine/ 
Dudik, A. (2021, 1 Mart). Russian Vaccine Gets Second EU Buyer as Slovakia Seals Order. Erişim adresi https://www.bloomberg.com/news/articles/2021-03-01/eu-member-slovakia-to-get-2-million-doses-ofrussian-vaccine

Engström, E. (2014). Contemporary Russian Messianism and New Russian Foreign Policy. Contemporary Security Policy, 35 (3), 356-379.

Foxall, A. (2019). From Evropa to Gayropa: A Critical Geopolitics of the European Union as Seen from Russia. Geopolitics, 24 (1), 174-193.

Frenkel, Sh., Abi-Habib, M., Barnes, J. E. (2021, 5 Şubat). Russian Campaign Promotes Homegrown Vaccine and Undercuts Rivals, The New York Times. Erişim adresi https://www.nytimes.com/2021/02/05/technology/russia-covid-vaccine-disinformation.html

Istomin, I. (2021). Institutional Revisionism in International Politics: The Product of Rising, the Child of Decline or Something Else?, Valdai Discussion Club Report, Moscow, 1-40.

Karaganov, S. veSuslov V. D. (2018, 4 Ekim). A New World Order: A View from Russia. Russia in Global Affairs. Erişim adresi https://eng.globalaffairs.ru/articles/a-new-world-order-a-view-from-russia/

Kennan, G. F. (1947). The Sources of Soviet Conduct. Foreign Affairs, 25 (4), 566-582.

Kowalewski, M. (2020). Street Protests in Times of COVID-19: Adjusting Tactics and Marching 'as usual'. Social Movement Studies, 1-8.

Kotkin, S. (2016). Russia's Perpetual Geopolitics: Putin Returns to the Historical Pattern. Foreign Affairs, 95 (3), 2-9.

Laruelle, M. (2015). The 'Russian World’: Russia's Soft Power and Geopolitical Imagination. Center on Global Interests, Washington, 1-29.

Light, F. ve Sauer, P. (2021, 19 Şubat). Looming Supply Glut of Russia's Sputnik V Vaccine Could Pave Way for Exports. Erişim adresi https://www.themoscowtimes.com/2021/02/19/looming-supply-glut-ofrussias-sputnik-v-vaccine-could-pave-way-for-exports-a73019

Lomsadze, G. (2021, 12 Ocak). Caucasus Vaccine Effort Infected with Geopolitics. Erişim adresi https://eurasianet.org/caucasus-vaccine-effort-infected-with-geopolitics

Mearsheimer, J. (2014 Eylül/Ekim). Why the Ukraine Crisis Is the West's Fault: The Liberal Delusions that Provoked Putin. Foreign Affairs, 93(5), 77-89.

Miskimmon, A., O'Loughlin B. ve Roselle L. (2013). Strategic Narratives: Communication Power and the New World Order. New York: Routledge.

Mölder, H. ve Sazonov, V. (2020). The Kremlin's Strategic Narratives on the Baltic States During the COVID-19 Crisis. The Bellona Quarterly, 703 (4), 35-54.

Pieper, M. (2020). Russkii Mir: The Geopolitics of Russian Compatriots Abroad. Geopolitics, 25 (3), 756-779.

Reuters. (2020, 28 Aralık). EU's Borrell Accuses Russia of Spreading COVID-19 Disinformation to Sell its Vaccine. Erişim adresi https://www.reuters.com/article/us-health-coronavirus-eu-russia-idUSKBN2921EI

Reuters. (2021, 10 Şubat). Ukraine Formally Bans Registration of Russian COVID-19 Vaccines. Erişim adresi https://www.reuters.com/article/health-coronavirus-ukraine-russia-idUSL1N2KG2EZ

Reuters. (2021, 13 Mayıs). Maldives Approves Russia's Sputnik V COVID-19 Vaccine. Erişim adresi https://www.reuters.com/article/health-coronavirus-vaccine-russia-maldiv-idUSR4N2MNOOD

RIA. (2021, 25 Ocak). Prezident Meksiki nazval vaktsinu 'Sputnik V' uspehom rossiyskoy nauki. Erişim adresi https://ria.ru/20210125/vaktsina-1594555913.html

Sputnikvaccine. (2021, 7 Mart). Sputnik V Authorized in North Macedonia. Erişim adresi https://sputnikvaccine.com/newsroom/pressreleases/sputnik-v-authorized-in-north-macedonia/

Tanner, J. (2021, 17 Şubat). Estonia Report: Russia Bets on COVID-19 Weakening the West. Erişim adresi https://apnews.com/article/europe-estonia-coronavirus-pandemic-covid-19-pandemic-europefbfc55618c3c26fecb5c966cf979f53d 
TASS. (2020, 11 Arallk). Visible to the Naked Eye: Kremlin Slams Big Pharma's Ploy to Smear Russia's COVID Vaccine. Erişim adresi https://tass.com/politics/1234019

TASS. (2020, 30 Aralık). West Obstructs Fighting COVID Pandemic in 'Undesirable' Countries, Lavrov Says. Erişim adresi https://tass.com/politics/1241325

TASS. (2021, 29 Ocak). Serbia Receives New Shipment of Russia's Sputnik V COVID-19 Vaccine. Erişim adresi https://tass.com/world/1250317

TASS. (2021, 3 Şubat). 'Way over the top': Lavrov Lambasts West's Hysteria over Navalny Case. Erişim adresi https://tass.com/politics/1252255.

The Baltic Times (2021, 8 Mart). Russia's Sputnik V Vaccine is Part of Hybrid War -Zelensky's Adviser in Vilnius - BNS Interview. Erişim adresi https://www.baltictimes.com/russia_s_sputnik_v_vaccine_is_part_of_hybrid_war_zelensky_s_adviser _in_vilnius___bns_interview/

The Moscow Times. (2020, 15 Aralık). Oliver Stone Receives Russian Coronavirus Vaccine Despite Age Concerns. Erişim adresi https://www.themoscowtimes.com/2020/12/15/oliver-stone-receives-russian-coronavirusvaccine-despite-age-concerns-a72355

Toal, G. (2017). Near Abroad: Putin, the West and the Contest Over Ukraine and the Caucasus. Oxford: Oxford University Press.

Twohey, M, Collins, K. ve Thomas, K. (2020, 15 Aralik ). With First Dibs on Vaccines, Rich Countries Have 'Cleared the Shelves'. The New York Times. Erişim adresi https://www.nytimes.com/2020/12/15/us/coronavirusvaccine-doses-reserved.html

Tyushka, A. (2021). Weaponizing Narrative: Russia Contesting EUrope's Liberal Identity, Power and Hegemony. Journal of Contemporary European Studies, https://doi.org/10.1080/14782804.2021.1883561 